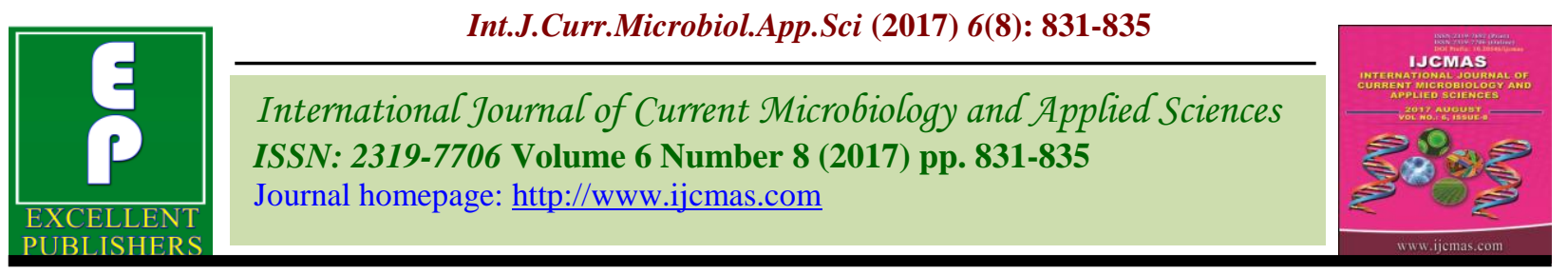

Original Research Article

https://doi.org/10.20546/ijcmas.2017.608.105

\title{
Yield and Economics of Moth bean [Vigna aconitifolia (Jacq.) Marechal] as Influenced by Different Varieties and Phosphorus Levels
}

\author{
Shishupal Singh ${ }^{1}$, Versha Gupta ${ }^{2}$, N.S. Yadava ${ }^{1}$ and S.P. Singh ${ }^{1}$ \\ ${ }^{1}$ Department of Agronomy, College of Agriculture, SKRAU, Bikaner, Rajasthan, India \\ ${ }^{2}$ Rajasthan College of Agriculture, MPUAT, Udaipur, India \\ *Corresponding author
}

\section{A B S T R A C T}

\begin{tabular}{|c|c|}
\hline Keywo & \multirow{4}{*}{$\begin{array}{l}\text { A field experiment was conducted on moth bean during kharif, } 2016 \text { at Agronomy Farm, } \\
\text { College of Agriculture, Bikaner. The experiment was laid out in randomized block design } \\
\text { with three replications. The treatments consisted of four varieties namely, RMO } 40, \mathrm{RMO} \\
225 \text {, RMO } 435 \text { and RMO } 257 \text { and four levels of phosphorus viz., } 20,40,60 \text { and } 80 \mathrm{P}_{2} \mathrm{O}_{5} \\
\mathrm{ha}^{-1} \text {. Variety RMO } 257 \text { recorded seed yield of } 827 \mathrm{~kg} \mathrm{ha}^{-1} \text { and established its significant } \\
\text { superiority over RMO } 225 \text { and RMO } 435 \text { in terms this respect over RMO } 225 \text { and RMO } \\
435 \text { by a margin of } 21.6 \text { and } 30.8 \text { per cent, respectively, nevertheless, variety RMO } 40 \text { was } \\
\text { statistically at par with RMO 257, suggesting it to be an alternative variety for the region } \\
\text { to be grown, as both the varieties being at par with each other, also recorded significantly } \\
\text { higher net returns as compared to RMO } 225 \text { and RMO } 435 \text {. Application of } 40 \mathrm{~kg} \mathrm{P}_{2} \mathrm{O}_{5} \mathrm{ha}^{-1} \\
\text { significantly increased the seed yield by a margin of } 39.7 \text { and net returns over } 20 \mathrm{~kg} \mathrm{P}_{2} \mathrm{O}_{5} \\
\text { ha }{ }^{-1} \text { and } 207 \text { per cent, respectively. Further increase in levels of phosphorus was not found } \\
\text { beneficial. }\end{array}$} \\
\hline & \\
\hline $\mathbf{A r}$ & \\
\hline & \\
\hline
\end{tabular}

\section{Introduction}

Among the leguminous kharif crops of arid western Rajasthan, moth bean [Vigna aconitifolia (Jacq.) Marechal] is of utmost significance due to its drought and heat tolerance characteristics. Above and beyond assured production under harsh and hostile arid environment, the crop conventionally supports dietary requirement of local people to a great extent by offering a range of edible products such as dried seeds, mature and immature green pods vegetable. Traditional preparations of moth bean like dal, kheech, papad, bhujia, mangori, etc. as a part of their food habits also fulfill the nutritional need of local people well, as it contains 22-24 per cent high quality protein along with high amount of essential amino acids particularly lysine and leucine and also certain vitamins (Kumar and Singh, 2001). Bikaneri bhujia, given identity to Bikaner in world trade, also carries the distinction of having a geographical indication tag from 2010 onwards. The credit of such recognition goes to one and only moth bean crop of this region, flour of which is used for the preparation of such a savory. The arid districts of Rajasthan are privileged to have moth bean as a traditional crop. It would not be out of place to mention that out of 85 per cent of moth bean area in Rajasthan, 93 per cent is confined to just 12 arid districts of the state. In Rajasthan, with an area of 9.27 lakh 
hectares and production of 2.67 lakh tones, the crop exhibits the productivity of $288 \mathrm{~kg}$ $\mathrm{ha}^{-1}$ (Krishi Rajasthan, 2015), which is still low in arid districts (about $200 \mathrm{~kg} / \mathrm{ha}$ ). During recent past, however, need based and deliberate attempts yielded success of desired level in developing the varieties of this hardy crop more productive and adaptive to harsher and more hostile environment. Quite a large variation in yielding performance of moth bean genotypes has been reported across the region and within the region among different years (Anonymous 2013, 2014, 2015 and 2016). Such variations convincingly demonstrate presence of genotypeenvironment interactions in moth bean and reasonably demand to evaluate the relative performance of different varieties particularly under changing climate scenario. The role and importance of phosphorus applications to pulse crops have long been recognized and is regarded as an essential prerequisite in the production of these leguminous crops. Phosphorus is not only essential for the development of root system but also plays a vital role in the formation of energy rich bond phosphates like Adenosine di phosphate (ADP), Adenosine tri phosphate (ATP), nucleoproteins, phospholipids, etc. It is also essential for the growth of bacteria responsible for nitrogen fixation. However, supply of phosphorus is more important than that of nitrogen because of nitrogen is fixed by the bacteria lodged in the root nodules of plant. Phosphorus application to moth bean has also been justified even in low-rainfall years because of its ability to improve yield under water-limited conditions (Garg et al., 2004)

\section{Materials and Methods}

The field experiment was conducted at Agronomy Farm, Collage of Agriculture, Swami Keshwanand Rajasthan Agricultural University, Bikaner during Kharif session of
2016. The soil of the experimental field was loamy sand in texture, alkaline in reaction, poor in organic carbon, low in available nitrogen and low in phosphorus but medium in available potassium. The experiment was laid out in randomized block design (R.B.D.) with three replications. Treatments are consisted of four varieties of moth bean viz. RMO 40, RMO 225, RMO 257 and RMO 435 and four levels of $\mathrm{P}_{2} \mathrm{O}_{5}$ viz. $20 \mathrm{~kg} \mathrm{ha}^{-1}, 40 \mathrm{~kg}$ ha $1,60 \mathrm{~kg} \mathrm{ha}^{-1}$ and $80 \mathrm{~kg} \mathrm{ha}^{-1}$ thus making 16 factorial combinations in all. As per treatment seed of different varieties duly treated with Rhizobium culture was sown @ $20 \mathrm{~kg} / \mathrm{ha}$ in lines spaced at $30 \mathrm{~cm}$ at a depth of $5 \mathrm{~cm}$ by "Kera" method in open furrows. For evaluating growth and yield attributes, five plants were randomly selected in each plot from the sampling rows and tagged permanently. At maturity, experimental crop was harvested from the net plot. The boarder rows were harvested separately. Threshing was done manually by beating and trampling the pods of each plot separately and grains were collected in numbered bags. After winnowing, cleaned seeds were weighted to record grain yield and expressed as $\mathrm{kg} \mathrm{ha}^{-1}$. Nutrient content and protein content in grain was determined by using standard methods.

\section{Results and Discussion}

\section{Effect of varieties}

Variety RMO 257 excelled all the remaining varieties namely, RMO 40, RMO 225 and RMO 435 in respect of number of pods per plant but, the difference with variety RMO 40 was not significant in this respect. In terms of other yield attributes viz., number of grains per pod, grain weight per pod and test weight studied, though all the varieties were statistically at par, yet RMO 257 slightly edged over others in these parameters. This might be due to the characteristics of this variety that reflected in increased vegetative 
growth. The growth characters play a vital role in various metabolic processes primarily that result in increased flowering and fruiting thereby improving pods per plant. These findings confirmed the results of Meena (2007) and Nehra and Shrama (2008). Variety RMO 257 also established it significant superiority over RMO 225 and RMO 435 in terms of seed yield, closely followed by RMO 40. The differential behaviour among the genotypes may be explained primarily on the basis of variation in their genetic makeup and secondly their differential behaviour under different agroclimatic conditions. Increased growth and yield attributing parameters observed with variety RMO 257 during crop growth period, in turn, played a crucial role in yield formation of this variety and accorded it superiority over others. It is pertinent to note that in terms of straw yield, all the varieties did not differ significantly from one another yet, in their biological yields considerable variations have been noticed that established variety RMO 257 superior to RMO 225 and RMO 435. This might be due to the fact that excess assimilates stored in the leaves and later their efficient translocation in to seeds at the time of senescence, ultimately led to higher seed yield of RMO 257 and RMO 40. Reports of Kandpal et al., 2006; Arora et al., (2008); Patel et al., (2008), etc. support our findings (Table 1).

\section{Effect of phosphorus levels}

It is evident that in comparison to $20 \mathrm{~kg} \mathrm{P}_{2} \mathrm{O}_{5}$ $\mathrm{ha}^{-1}$, all the other levels of phosphorus brought about significant improvement in number of pods per plant, number of grains per pod and grain weight per pod, however, successive doses beyond $40 \mathrm{~kg} \mathrm{P}_{2} \mathrm{O}_{5} \mathrm{ha}^{-1}$ failed to bring about significant improvement in these attributes. The regulatory functions of phosphorus in photosynthesis and carbohydrate metabolism of leaves can be considered as one of the major factors that governs plant growth particularly during reproductive phase. The availability of phosphorus during this period regulates starch/sucrose ratio in the source and sink. Probably, this effect of phosphorus on partitioning is also responsible, in part, for the insufficient supply of photosynthates to the nodulated roots of legumes grown under phosphorus deficient soils. Seed yield was found to be increased significantly with increase in phosphorus levels up to $40 \mathrm{~kg}$ $\mathrm{P}_{2} \mathrm{O}_{5} \mathrm{ha}^{-1}$, successive increase in phosphorus levels up to $80 \mathrm{~kg} \mathrm{P}_{2} \mathrm{O}_{5} \mathrm{ha}^{-1}$, however, could not bring about significant improvement in seed yield. This might be due to concomitant performance of crop in terms of number of pods per plant, number of seeds per pod and grain weight per pod.

\section{Economics}

\section{Net returns (Rs.ha $\left.{ }^{-1}\right)$}

Variety RMO 257 recorded the highest net returns of Rs13412 ha $^{-1}$ which is significantly higher than that recorded with RMO 225 and RMO 435. Variety RMO 40 was at par with RMO 257 in this respect. And when compared with level $20 \mathrm{~kg} \mathrm{P}_{2} \mathrm{O}_{5}$, though at the other levels gave significant increment in net monetary returns application of beyond $40 \mathrm{~kg}$ $\mathrm{ha}^{-1}$ failed to record significant increment in net returns (Table 2).

\section{B.C. ratio}

Variety RMO 257 recorded the highest B:C ratio (1.68) followed by RMO 40, RMO 225 and $\mathrm{RMO}$ 435.And the lowest $\mathrm{B}: \mathrm{C}$. ratio was recorded with the application of $60 \mathrm{~kg} \mathrm{P}_{2} \mathrm{O}_{5}$ $\mathrm{ha}^{-1}$ which was closely followed by level 40 $\mathrm{kg} \mathrm{P}_{2} \mathrm{O}_{5} \mathrm{ha}^{-1}$. 
Table.1 Effect of varieties and phosphorus levels on yield attributes: number of pods plant ${ }^{-1}$, number of grain pod ${ }^{-1}$, grain weight, and test weight of moth bean

\begin{tabular}{|c|c|c|c|c|}
\hline Treatment & $\begin{array}{c}\text { Number } \\
\text { of pods } \\
\text { plant }^{-1}\end{array}$ & $\begin{array}{l}\text { Number of } \\
\text { grain } \text { pod }^{-1}\end{array}$ & $\begin{array}{l}\text { Grain weight } \\
\text { (mg) }\end{array}$ & Test weight (g) \\
\hline \multicolumn{5}{|l|}{ Varieties } \\
\hline RMO 40 & 32.20 & 5.77 & 143.00 & 26.71 \\
\hline RMO 225 & 27.43 & 5.40 & 138.67 & 27.47 \\
\hline RMO 257 & 32.92 & 5.53 & 143.67 & 27.63 \\
\hline RMO 435 & 26.32 & 5.20 & 135.08 & 27.74 \\
\hline S.Em. \pm & 1.49 & 0.16 & 3.29 & 0.40 \\
\hline $\mathrm{CD}(p=0.05)$ & 4.30 & NS & NS & NS \\
\hline \multicolumn{5}{|c|}{ Phosphorus levels $\left(\mathrm{kg} \mathrm{P}_{2} \mathrm{O}_{5} \mathrm{ha}^{-1}\right)$} \\
\hline 20 & 21.77 & 5.00 & 127.58 & 27.01 \\
\hline 40 & 31.48 & 5.68 & 144.00 & 26.96 \\
\hline 60 & 33.07 & 5.67 & 144.25 & 27.88 \\
\hline 80 & 32.55 & 5.55 & 144.58 & 27.70 \\
\hline S.Em. \pm & 1.49 & 0.16 & 3.29 & 0.40 \\
\hline $\mathrm{CD}(p=0.05)$ & 4.30 & 0.45 & 9.50 & NS \\
\hline
\end{tabular}

Table. 2 Effect of cultivars and levels of phosphorus on yields and economics of moth bean

\begin{tabular}{|c|c|c|c|c|}
\hline Treatment & $\begin{array}{c}\text { Seed } \\
\text { yield } \\
\left(\mathrm{kg} \mathrm{ha}^{-1}\right)\end{array}$ & $\begin{array}{l}\text { Straw yield } \\
\left(\mathrm{kg} \mathrm{ha}^{-1}\right)\end{array}$ & $\begin{array}{l}\text { Net Returns } \\
\text { (Rs. /ha) }\end{array}$ & $\begin{array}{l}\text { B:C } \\
\text { ratio }\end{array}$ \\
\hline \multicolumn{5}{|l|}{ Varieties } \\
\hline RMO 40 & 799 & 1912 & 12376 & 1.63 \\
\hline RMO 225 & 680 & 1854 & 8068 & 1.40 \\
\hline RMO 257 & 827 & 1945 & 13412 & 1.68 \\
\hline RMO 435 & 632 & 1748 & 6179 & 1.31 \\
\hline S.Em. \pm & 30. & 72 & 1148 & - \\
\hline $\mathrm{CD}(p=0.05)$ & 87 & NS & 3315 & - \\
\hline \multicolumn{5}{|c|}{ Phosphorus levels (kg $\left.\mathrm{P}_{2} \mathrm{O}_{5} \mathrm{ha}^{-1}\right)$} \\
\hline 20 & 551 & 1344 & 3804 & 1.21 \\
\hline 40 & 770 & 1865 & 11686 & 1.61 \\
\hline 60 & 805 & 2097 & 12539 & 1.63 \\
\hline 80 & 812 & 2153 & 12006 & 1.57 \\
\hline S.Em. \pm & 30 & 72 & 1148 & - \\
\hline $\mathrm{CD}(p=0.05)$ & 87 & 207 & 3315 & - \\
\hline
\end{tabular}

In conclusion, the present investigation has led to the inference that variety RMO 257 is superior to RMO 225 and RMO 435 as it (variety RMO 257) recorded significantly higher seed yield of $827 \mathrm{~kg} \mathrm{ha}^{-1}$ and net monetary returns of Rs $13412 \mathrm{ha}^{-1}$, closely 
followed by RMO 40, which can also be an alternative choice for the cultivation of moth bean in the region. As well as application of phosphorus @ $40 \mathrm{~kg} \mathrm{ha}^{-1}$ found better as compared to other levels in terms of seed yield $\left(770 \mathrm{~kg} \mathrm{ha}^{-1}\right.$ ) and net returns (Rs.11686 $\mathrm{ha}^{-1}$ ) as further increase in levels of phosphorus i.e. 60 and $80 \mathrm{~kg} \mathrm{P}_{2} \mathrm{O}_{5} \mathrm{ha}^{-1}$ did not bring about significant improvement in yield and net returns.

\section{References}

Anonymous. 2013. Annual Progress Report, National Network Research Project on Arid Legumes, pp.113-121.

Anonymous. 2014. Annual Progress Report, Network Research Project on Arid Legumes, pp119-124.

Anonymous. 2015. Annual Progress Report, Network Research Project on Arid Legumes, pp 52-54.

Anonymous. 2016. Annual Progress Report of Network Research Project on Arid Legumes, pp 52-56.

Arora, D., Rathore, K.S. and Garhwal, O.P. 2008. Performance of mothbean (Vigna aconitifolia L.) varieties under Arid conditions of Nagaur district. $3^{\text {rd }}$ National symposium on enhancing productivity, Nutritional security and export Potential through Arid Legumes, pp. 133-134.

Garg, K.B., Burman Uday and Kathju Shyam. 2004. The influence of phosphorus nutrition on the physiological response of moth bean genotypes to drought. $J$. Plant Nutrition and Soil Sci., 167(4): 503-508.

Kandpal, B.K., Mertia, R.S. and Kumawat, R.N. 2006. Evaluation of Vigna aconitifolia genotypes for their suitability to aeolian plains of extreme arid region. J. Arid Legumes, 3(1): 3033.

Kumar, D. and Singh, N.B. 2001. Moth bean Agronomy in Moth bean in India Scientific Publishers, Jodhpur. Pp. 73.

Meena, B.L. 2007. Studies on the response of moth bean (Vigna aconitifolia) cultivars to different levels of phosphorus in arid region of Rajasthan. M.Sc. (Ag.) Thesis, Rajasthan Agricultural University, Bikaner.

Nehra, K.C. and Sharma, S.R. 2008. Response of different fertilizer levels on new varieties of moth bean in north western plain zone of Rajasthan. $3^{\text {rd }}$ National Symposium on Enhancing productivity, Nutritional Security and Export Potential through Arid Legume pp-57.

Patel, A.M., Patel, P.S., Patel, P.G. and Patel, D.G. 2008. Production potential of different moth bean [Vigna aconitifolia (Jacq.) Marechal] varieties under north Gujarat condition. $3^{\text {rd }}$ National symposium on enhancing productivity, Nutritional security and export Potential through Arid Legumes. June pp. 66.

\section{How to cite this article:}

Shishupal Singh, Versha Gupta, N.S. Yadava and S.P. Singh. 2017. Yield and Economics of Moth bean [Vigna aconitifolia (Jacq.) Marechal] as Influenced by Different Varieties and Phosphorus Levels. Int.J.Curr.Microbiol.App.Sci. 6(8): 831-835. doi: https://doi.org/10.20546/ijcmas.2017.608.105 